\title{
Oxidative Stress: Importance for Postharvest Quality
}

\author{
D. Mark Hodges ${ }^{1}$ \\ Atlantic Food and Horticulture Research Centre, Agriculture and Agri-Food Canada, 32 Main Street, Kentville, Nova \\ Scotia, Canada, B4N $1 J 5$
}

Gene E. Lester

Kika de la Garza Subtropical Agricultural Research Center, Agriculture Research Service, U.S. Department of Agriculture, 2413 East Highway 83, Building 200, Weslaco, TX 78596

\author{
Kathleen D. Munro \\ Atlantic Food and Horticulture Research Centre, Agriculture and Agri-Food Canada, 32 Main Street, Kentville, Nova \\ Scotia, Canada, B4N $1 J 5$
}

\author{
Peter M.A. Toivonen \\ Pacific Agri-Food Research Centre, Agriculture and Agri-Food Canada, Summerland, British Columbia, \\ Canada, V2A 8 A6
}

\begin{abstract}
Commencing in the middle to late 1980s, plant physiologists began to examine oxidative stress. Initial interests focused on how oxidative stress was associated with plant stress due to environmental perturbations such as chilling temperatures (Hodges, 2001; Hodges et al., 1997), water status (Li et al., 1998), salinity (Gossett et al., 1994), ozone exposure (e.g., Conklin and Last, 1995), and UV irradiation (Hideg et al., 1997). Later, this expanded to studies of other roles where oxidative stress influences plant metabolism, such as in cell signaling, where active oxygen species function as stress and secondary messengers involved in the stress-response signal transduction pathway (Delledonne et al., 2001; Mittler, 2002; Price et al., 1994). Oxidative stress has also become widely studied in relation to medical science, which has associated oxidative injury with such dysfunctions as cancer, heart disease, and certain neurological disorders (Ames et al., 1993; German et al., 1997; Halliwell, 1996; Hodges and Kalt, 2003; Meydani, 1999). As fresh fruits and vegetables experience many types of stress during processing, storage, and/or transport, an increasing amount of research is being generated on how oxidative stress is associated with postharvest quality.
\end{abstract}

\section{OXIDATIVE STRESS}

Oxidative stress occurs when the generation of active oxygen species (AOS) exceeds the capacity of the plant to maintain cellular redox homeostasis, or, more simply, when the production of active oxygen species exceeds the capacity of the plant to scavenge them. Active oxygen species are partially reduced forms of molecular oxygen $\left(\mathrm{O}_{2}\right)$, resulting from either the excitation of $\mathrm{O}_{2}$ to form singlet oxygen $\left({ }^{1} \mathrm{O}_{2}\right)$ or the transfer of one, two, or three electrons to $\mathrm{O}_{2}$ to form, respectively, superoxide $\left(\mathrm{O}_{2}^{-}\right)$, hydrogen peroxide $\left(\mathrm{H}_{2} \mathrm{O}_{2}\right)$, or the hydroxyl radical $(\cdot \mathrm{OH})$. With the exception of the highly unspecific $\cdot \mathrm{OH}$, AOS exhibit specificities for various cellular components and, dependent upon availability and concentration of cellular targets, have an average lifetime measuring in the nanoseconds (e.g., $\cdot \mathrm{OH})$ to milliseconds (e.g., $\left.\mathrm{O}_{2}^{-}, \mathrm{H}_{2} \mathrm{O}_{2}\right)($ Saran et al., 1988). Lipids, proteins, carbohydrates, and nucleic acids are all targets of AOS (Hodges, 2003a). Chloroplasts, mitochondria, nuclei, glyoxysomes, and peroxisomes all represent major sites of AOS production, though the importance of chloroplastic sources may decrease in ripening fruits and commodities placed in dark storage.

It has been well-documented that environmental stresses such as temperature extremes (Hodges, 2001), salinity (Gossett et al., 1994), drought (Li et al., 1998), ozone exposure (Conklin and Last, 1995), and UV irradiation (Hideg et al., 1997) induce production of AOS, often leading to oxidative stress. For plants, typical symptoms of oxidative stress include inhibition of chloroplast development (Poskuta et al., 1974), the development of classical postharvest disorders such

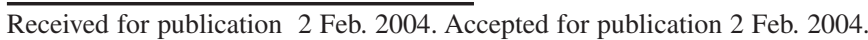
Atlantic Food and Horticulture contribution 2273. The authors wish to thank Charles F. Forney and John M. DeLong for critical review of this manuscript. ${ }^{1}$ Corresponding author; email HodgesM@ agr.gc.ca. as superficial scald (DeLong and Prange, 2003) and core browning (Larrigaudiere et al., 2001), bleaching of pigments (Elstner and Osswald, 1994), disruptions in membrane integrity (Biedinger et al., 1990), the inactivation of many types of functional proteins (e.g., enzymes) resulting from damage followed by subsequent attacks by proteases (Casano et al., 1994; Landry and Pell, 1993), and lesions and mutations of nucleic acids. Active oxygen species have also been implicated in the regulation, properties, and/or dynamics of induced or natural senescent processes (Droillard et al., 1987; Hodges and Forney, 2003; Philosoph-Hadas et al., 1994; Thompson et al., 1991). Indeed, one of the major characteristics of senescence in plant tissues is increased lipid peroxidation (Kunert and Ederer, 1985; Lacan and Baccou, 1998). Lipid peroxidation is also thought to play an important role in the biosynthesis of ethylene (Paulin et al., 1986), a hormone involved in senescence regulation. Although the exact mechanism of ethylene induction under these circumstances is unclear, it may arise as a lipid-fragmentation product through reactions of lipoxygenase (Gardner and Newton, 1987), an enzyme catalyzing the production of hydroperoxy conjugated dienes from polyunsaturated fatty acids, or perhaps through increased accessibility of its precursor 1-aminocyclopropane-1-carboxylic acid (ACC) to ACC oxidase as a result of membrane deterioration (Pell et al., 1997).

\section{OXIDATIVE STRESS RESISTANCE}

As with any stress, plants normally have two primary strategies of coping with oxidative stress: they can either avoid it or tolerate it. Not surprisingly, as postharvest fruits and vegetables rarely will be in the position to actively avoid oxidative stress themselves, only actions taken to remove the commodity from a situation which may induce AOS over-production will allow for the avoidance strategy. However, similar to growing plants, tolerance to oxidative stress of postharvest fruits and vegetables has been associated with such factors as waterand lipid soluble antioxidant capacities (Hodges and Forney, 2000, 2003), regulation of AOS production (Duque and Arrabaça, 1999), and membrane composition (Zabrouskov et al., 2002).

\section{FACTORS INFLUENCING POSTHARVEST OXIDATIVE STRESS}

\footnotetext{
"External" factors such as production factors (e.g., harvest maturity) (Gong et al., 2001; Masia, 1998), harvest procedures, storage duration (Hodges and Forney, 2000), storage temperature (Wismer, 2003), storage atmosphere (Gunes et al., 2002), processing protocols (Hodges et al., 2000; Pirker et al., 2002), conditions exacerbating water loss (Toivonen, 2003), senescence and/or ripening of the commodity (Aharoni et al., 2002; Lacan and Baccou, 1998; Lester, 2003), as well as internal factors such as genotype (Hodges et al., 2001), can all contribute to inducing oxidative stress of postharvest fruits and vegetables (Table 1). More than one of these factors can occur simultaneously or consecutively to exacerbate oxidative damage.
} 
Table 1. Summary of measured indicators ${ }^{\mathrm{z}}$ of oxidative stress as reported in postharvest literature until 2002 . This is not an exhaustive list, but is used to illustrate the range of measures made which are indicative of oxidative injury in postharvest studies. Information extracted from Hodges (2003b).

\begin{tabular}{|c|c|c|c|c|c|c|}
\hline Factors & $\begin{array}{c}\text { Visible } \\
\text { observations }\end{array}$ & $\begin{array}{l}\text { Antioxidant } \\
\text { content }\end{array}$ & $\begin{array}{c}\text { Antioxidant } \\
\text { enzymes }\end{array}$ & $\begin{array}{l}\text { Oxidative } \\
\text { products }\end{array}$ & $\begin{array}{l}\text { Active } \mathrm{O}_{2} \\
\text { species }\end{array}$ & $\begin{array}{l}\text { Membrane } \\
\text { degradation }\end{array}$ \\
\hline Maturity & $\begin{array}{l}\text { Scald, core and flesh } \\
\text { browning, pitting }\end{array}$ & $\begin{array}{l}<\mathrm{LSA},<\mathrm{WSA}, \\
<\text { anthocyanins, } \\
<\text { phenols }\end{array}$ & $\begin{array}{l}<\mathrm{SOD},<\mathrm{CAT}, \\
>\mathrm{GR}\end{array}$ & >Lipid hydroperoxides, & & \\
\hline Storage duration & Decline in quality & $>$ tocopherol & $\pm \mathrm{SOD}, \pm \mathrm{CAT}$ & >Lipid hydroperoxides, & & Increased \\
\hline \multicolumn{7}{|l|}{ Storage temperature } \\
\hline Superoptimal & Yellowing & $\begin{array}{l} \pm \text { ascorbate } \\
<\text { carotenoids }\end{array}$ & $\begin{array}{l}>\text { SOD },>\text { CAT, } \\
>\text { POD }\end{array}$ & >Lipid hydroperoxides, & & \\
\hline Suboptimal & $\begin{array}{l}\text { Pitting, abnormal ripening, } \\
\text { flesh browning, sweetening }\end{array}$ & $\begin{array}{l}<\text { ascorbate, }<\mathrm{GSH}, \\
<\text { tocopherol }\end{array}$ & $\begin{array}{l} \pm \mathrm{SOD}, \pm \mathrm{CAT} \\
>\mathrm{POD},>\mathrm{ASPX}\end{array}$ & $\begin{array}{l}\text { > Lipid hydroperoxides, } \\
\text { > peroxides, >MDA }\end{array}$ & $\begin{array}{l}>\mathrm{H}_{2} \mathrm{O}_{2},>\mathrm{O}_{2}^{-}, \\
>\cdot \mathrm{OH}^{-}\end{array}$ & Increased \\
\hline Water loss & Decline in quality & $\begin{array}{l}<\text { ascorbate } \\
<\text { carotenoids }\end{array}$ & increased & & & \\
\hline \multicolumn{7}{|l|}{ Atmosphere } \\
\hline High $\mathrm{CO}_{2}$ & Flesh browning & $<$ LSA, $<$ ascorbate & $\begin{array}{l}<\mathrm{ASPX},<\mathrm{CAT}, \\
>\text { DHAR }\end{array}$ & & & Increased \\
\hline Low $\mathrm{O}_{2}$ & Reduced scald & $>$ ascorbate & $>\mathrm{SOD},>\mathrm{CAT}$ & $<\alpha$-Farnesene* & & Reduced \\
\hline Ethylene & $\begin{array}{l}\text { Yellowing, scald, } \\
\text { russeting }\end{array}$ & $>$ ascorbate & $\begin{array}{l}>\mathrm{ASPX},>\mathrm{CAT}, \\
<\mathrm{DHAR},<\mathrm{GR}, \\
<\mathrm{SOD}\end{array}$ & $\begin{array}{l}\text { >Lipid hydroperoxides, } \\
>\text { MDA, } \\
>\alpha \text {-farnesene* }\end{array}$ & $>\mathrm{H}_{2} \mathrm{O}_{2}$ & \\
\hline Irradiation & $\begin{array}{l}\text { Browning, abnormal } \\
\text { ripening, scald, tissue } \\
\text { breakdown }\end{array}$ & $\begin{array}{l} \pm \mathrm{GSH}, \pm \text { carotenoids, } \\
\pm \text { ascorbate }\end{array}$ & & >DNA fragmentation & $>\mathrm{O}_{3},>\mathrm{H}_{2} \mathrm{O}_{2}$ & Increased \\
\hline
\end{tabular}

${ }^{\mathrm{L}} \mathrm{LSA}=$ lipid soluble antioxidants, $\mathrm{WSA}=$ water soluble antioxidants, $\mathrm{SOD}=$ superoxide dismutase, $\mathrm{CAT}=$ catalase, GR $=$ glutathione reductase, $\mathrm{POD}=$ peroxidase, $\mathrm{GSH}=$ reduced glutathione, $\mathrm{MDA}=$ malondialdehyde, $\mathrm{O}_{2}^{-}=$superoxide anion, $\cdot \mathrm{OH}=$ hydroxyl radical, $\mathrm{ASPX}=$ ascorbate peroxidase, $\mathrm{DHAR}=$ dehydroascorbate reductase, $\alpha$-farnesene ${ }^{*}=$ oxidized $\alpha$-farnesene.

\section{Harvest maturity}

Oxidative-related injury disorders are highly dependent upon the harvest maturity of the fruit or vegetable, an observation hypothesized to be related to scavenging capacities of such antioxidant enzymes as superoxide dismutase (SOD), catalases (CAT), peroxidases (POX), and glutathione reductase (GR) and antioxidant compounds such as carotenoids, tocopherols, and ascorbate (Toivonen, 2003). For example, disorders such as fruit scald have been associated with antioxidant capacity (Barden and Bramlage, 1994a; DeLong and Prange, 2003; Lentheric et al., 2003), which is in turn related to harvest maturity (Toivonen, 2003). Barden and Bramlage (1994b) reported that levels of lipid-soluble antioxidants during apple storage depended on original harvest levels; higher antioxidant levels from later harvest dates were necessary to ensure sufficient antioxidant protection from scald. Maturation of saskatoon fruit was accompanied by increases in oxidative stress and a concomitant decline in SOD and CAT activities (Rogiers et al., 1998).

Although in one study anthocyanin levels in blueberries increased with harvest maturity, oxygen-radical absorbing capacity (ORAC) and phenolic content were lower in more ripe fruit (Kalt et al., 2003). These results are apparently cultivar and/or growing region dependent as another study with the blueberry cultivar Elliot showed increases in antioxidant activity, total phenolic content, and anthocyanin content with fruit maturity (Connor et al., 2002). A decline in phenolic content during ripening does not always occur in berry crops; a substantially higher level of total phenolics was observed in red ripe raspberry compared to pink underripe fruit (Wang and Lin, 2000). Tomatoes picked at the mature-green stage also developed higher levels of lycopene, $\beta$-carotene, and ascorbate than fruit picked at the ripe stage (Giovanelli et al., 1999).

The influence of harvest maturity of fruits and vegetables on oxidative stress can often also be attributed to senescence and ripening factors, both discussed in more detail later in this paper.

\section{Storage temperature}

Storage temperatures for fruits and vegetables are selected to optimize quality attributes such as texture, flavor, and appearance over time. Low-temperature storage extends shelf life of plant commodities, but product-specific temperature thresholds exist beyond which symptoms of chilling-induced oxidative injury and oxidative-related disorders will occur (Toivonen, 2003; Wismer, 2003). Superoptimal storage temperatures may also accelerate oxidatively induced senescence (Zhuang et al., 1997). However, moderate heat treatment of certain horticultural commodities before storage appears to diminish the effects of applied oxidative stress (Lurie, 1998).
Since low temperature is used to extend the shelf life of various fruits and vegetables, the temperatures at which commodities experience chilling-induced oxidative stress have been well studied. In chilling-sensitive commodities, cold temperatures impair the energy state of the cell and/or provoke alterations in membrane integrity (Bartosz, 1997; Purvis and Shewfelt, 1993). This may result in enhanced AOS proliferation, while also reducing scavenging efficacy through such factors as chilling-related inactivation of antioxidants and/or impeded antioxidant turn-over (Bartosz, 1997; Wismer, 2003).

Membrane lipid peroxidation may be one of the first events in the manifestation of chilling injury. Ethane evolution, an indicator of membrane lipid peroxidation, was observed from cucumber fruit after $3 \mathrm{~d}$ storage at $4{ }^{\circ} \mathrm{C}$ followed by $8 \mathrm{~d}$ rewarming, while no visible signs of chilling injury were apparent (Parkin and Kuo, 1989). Profiles of antioxidant compounds may be altered in response to low temperature extremes. Sala (1998) found that SOD activity increased in both chilling-sensitive and chilling-tolerant varieties of mandarin flavedo tissue, while CAT, ascorbate peroxidase (ASPX), and GR increased in the chilling-tolerant cultivars. Purvis et al. (1995) observed that mitochondria are a source of oxidative stress during chilling as superoxide production from the electron transport chain is increased in chilling-sensitive green bell peppers. Storage disorders, such as lowtemperature sweetening, superficial scald, pitting, and core browning, are related to low-temperature-induced oxidative stress (Toivonen, 2003; Wismer, 2003).

Chilling temperatures alter the equilibrium between AOS generation and defense mechanisms such that oxidatively induced chilling injury is observed (Hodges, 2001). Chilling-tolerant plants or plant parts may initially contain or can generate more antioxidants during stress and/or produce fewer AOS than more chilling-sensitive plant species (Wismer, 2003).

\section{Storage atmosphere}

Altering fruit and vegetable storage environments through controlled atmospheres (CA) or modified atmosphere packaging (MAP), which decreases respiration and metabolism, generally reduces oxidative stress, tissue senescence, sensitivity to ethylene, low temperature injury, and pathogen/insect damage (for review, see Toivonen, 2003). Harmful effects of misapplied CA or MAP can include off-flavors due to low oxygen levels, membrane damage due to stressful low oxygen or high carbon dioxide levels and inhibition of periderm development, resulting in tissue water-loss stress.

Modified atmosphere packaging of broccoli enclosed in $7.5 \% \mathrm{CO}_{2}$ 
plus $11.2 \% \mathrm{O}_{2}$ vs. air decreased oxidative stress through the retention of ascorbic acid, carotenoids, chlorophyll, and polyunsaturated fatty acids (Zhuang et al., 1994, Barth and Zang, 1996; Toivonen, 2003). Tocopherol levels, however, did not change in this MAP but were increased in air. The increase in tocopherol was accompanied by a concomitant loss in ascorbic acid, presumably due to ascorbic acid being associated with tocopherol regeneration (Kunert and Ederer, 1985). Lowering $\mathrm{O}_{2}$ to $<3 \%$ significantly improved the retention of ascorbic acid in 'Niitaka' pear fruit, and reduced membrane leakage and prevented skin discoloration (Yang, 1997). However, in another pear variety, 'Conference' (Larrigaudiere et al., 2001), CA (2\% $\mathrm{O}_{2}$ and $5 \% \mathrm{CO}_{2}$ ) storage resulted in an accumulation of membrane breakdown products resulting from lipid peroxidation and a significant increase in activity of the autocatalytic degradation pathway due to an increase in lipoxygenase activity and $\mathrm{H}_{2} \mathrm{O}_{2}$ levels. Controlled or modified atmosphere effects on oxidative stress appear to be commodity specific (Hodges and Forney, 2000) but, if administered correctly, should greatly reduce or suspend oxidative stress by decreasing activity of the autocatalytic degradation pathway and preserving human nutritional and market quality attributes.

\section{Water status}

As chilling injury is associated with tissue water loss, high humidity during product storage reduces chilling injury (Forney and Lipton, 1990). In nonchilling situations, wilting has been associated with declines in antioxidants, as observed with ascorbic acid in kale, cabbage and snap bean, and in carotene in kale, collards and turnip greens (Toivonen, 2003). Water loss has been shown to cause excessive production of AOS, specifically $\mathrm{H}_{2} \mathrm{O}_{2}$ in plant tissues (Yan et al., 2003). Provision of high humidity atmospheres through MAP or selective gas permeable plastic wraps prevented the development of chilling injury in mangos (Pesis at al. 2000) and prevented the loss of carotene, fruit sugars, nonenzymatic browning, membrane integrity and fresh weigh of netted muskmelon fruit, while maintaining fruit firmness and marketable appearance (Lester and Bruton, 1986). In the retail display, case misting, as a means of reducing tissue water loss at nonrefrigerated temperatures, reduces tissue water loss and promotes the retention of ascorbic acid and total carotenes (Barth and Zhuang, 1996).

\section{Processing}

Physical abrasions, processing temperatures, and product preservation techniques may all induce an increase in oxidative stress (e.g., Hodges et al., 2000). For example, Pirker et al. (2002) harvested differentially field drought-stressed strawberries and analyzed them for free radical levels after they had been frozen or freeze-dried. Although unfortunate that free radical levels in fresh strawberry tissue were not evaluated for comparative purposes, these authors discovered that the free radical content of the freeze-dried samples was approximately 10fold higher than that in the equivalent frozen samples. Moreover, the free radical content of the freeze-dried fruit was inversely related to the initial level of drought-stress to which the fruit was exposed.

In a study comparing air and MAP storage and cooking in water on the ascorbate content of fresh-cut spinach, a decrease in the total antioxidant activity was observed during $7 \mathrm{~d}$ of storage, but ascorbate levels were better preserved in MAP atmospheres (Gil et al., 1999). Boiling spinach in water for 10 min resulted in $60 \%$ of the ascorbate being extracted into the surrounding water.

Ionizing (gamma and electron beam) irradiation induces the development of oxygen radicals that can lead to oxidative injury in fruit and vegetable tissues (Toivonen, 2003). Ionizing irradiation produces ozone in air and any oxygen-containing plant tissues, specifically the air-filled apoplasts (Maxie and Abdel-Kader, 1966). Irradiation has been shown to produce many varied forms of oxygen radicals in addition to damaging plant membranes, proteins and DNA (Jones and Bulford, 1990). The U.S. Food and Drug Administration's upper limit of irradiation applied to all fresh fruits and vegetables is $1 \mathrm{kGy}$. However doses of $0.2 \mathrm{kGy}$ have been shown to cause severe membrane damage to green banana peels (Strydom et al., 1991), lower sensitivity to ethylene in apples (Abeles, 1973), increase electrolyte leakage (Lester and Wolfenbarger, 1990) and decrease ascorbic acid (GarciaYanez et al., 1990) and glutathione (Toyo'oka et al., 1989) levels in grapefruit, de-esterification of phospholipids in cauliflower (Voisine et al., 1991), and losses in carotenoids in potatoes (Michell et al., 1990). Although there are many examples of oxidative injury due to ionizing irradiation, a perceptible decline in marketable quality and nutritional value may be considered marginal if appropriate does/rates are applied (Toivonen, 2003). Lester and Wolfenbarger (1990) found that a $0.25 \mathrm{kGy}$ dose applied at an increasing period of time (rate) of $1 \mathrm{~min}$ vs. $2.5,5$, or 25 min greatly reduced measurable membrane damage (electrolyte leakage), loss of total phenols and ascorbic acid levels in fresh grapefruit. Kader (1986) outlines the recommended safe use of ionizing irradiation for fresh fruits and vegetables.

Although most irradiation damage is deliberate, resulting from gamma and electron beam disinfestations applications, irradiation from light, i.e., UV-B and UV-C UValso can affect AOS levels during fruit ripening. Schmitz-Eiberger and Noga (2001) found significant changes to green bean seedling leaves with elevated UV-B $(280-320 \mathrm{~nm})$ irradiation. UV-B- induced injury resulted in a disturbance of the active oxygen metabolism system by destroying nonenzymatic and altering the enzymatic defense systems. Barka (2001) showed that immediately upon low level $\left(3.7 \mathrm{~kJ} \cdot \mathrm{m}^{-2}\right) \mathrm{UV}-\mathrm{C}$ light $(254 \mathrm{~nm})$ irradiation superoxide dismutase and ascorbate oxidase activities are decreased and lipoxygenase and phenylalanine ammonia lyase activities are increased in tomato fruit. Much is still unknown about light irradiation and oxidative stress in fresh fruits and vegetables in relation to ionizing irradiation, and therefore is an important future research direction.

\section{Senescence}

Senescence in plant tissues is associated with excess production of AOS, and is considered the terminal phase of life of plant organs including leaves, flowers and fruits (Buchanan-Wollaston, 1997). Evidence for the involvement of AOS in senescence in plant physiology has been shown in such diverse plant parts as petals, maize ear shoot silks, and pea nodules (Watkins and Rao, 2003). However, the most investigated plant tissue regarding senescence and AOS are leaves; in senescing leaf systems lipid peroxidation is typically associated with a decline in catalase and superoxide dismutase activities, heightened levels of $\mathrm{H}_{2} \mathrm{O}_{2}$ and reduced transcription of mRNA (Watkins and Rao, 2003). Postharvest treatments that delay senescence, such as calcium, are associated with lower $\mathrm{H}_{2} \mathrm{O}_{2}$ levels in cucumber cotyledons (Ferguson et al., 1983) and lower lipoxygenase activities in netted and honey dew muskmelon fruit (Lester and Grusak, 1999). Few studies have attempted to identify differences in AOS activities in relation to different rates of senescence among fruits and vegetables (Hodges et al., 2001). Du and Bramlage (1994) found that total SOD activity (i.e., $\mathrm{CuZn-SOD,Fe-SOD}$ and Mn-SOD) changed greatly during senescence of various apple cultivars. Recently, Jimenez et al. (2003), comparing green versus red peppers (Capsicum annumm), demonstrated that numerous antioxidants have a role in pepper senescence. Superoxide diumutase isozymes (Mn-SOD, Fe-SOD and CuZn-SOD), GR, CAT and ASPX exhibited higher activity levels in the red (more senescent) than in the green (less senescent) fruit. Conversely, monodehydroascorbate reductase and dehydroascorbate reductase activities were higher in the green fruit. Results implied that SODs, CAT and ASPX are highly involved in pepper fruit senescence. Breeding for improved or heightened oxidative stress defense was recently accomplished by transgenic manipulation, where CuZn-SOD levels were elevated in cucumber fruit (Lee et al., 2003).

It is encouraging to see that genetic modification technology is occurring as these studies will determine whether changes in enzymes associated with AOS metabolism are due to altered biosynthesis, activation, and/or degradation (Watkins and Rao, 2003).

\section{Ripening}

According to Masia (2003), the onset of ripening results in rapid changes in cellular components, an increase in catabolic processes, and the initiation of senescence. Therefore ripening, which involves developmental changes in color, firmness, sugar, flavor, and proteins, can be differentiated from senescence, which involves a loss of membrane integrity (Noodén, 1988). One way of looking at ripening is that it can be seen as a protracted form of fruit senescence during which levels of AOS progressively increase, mainly as a result of the declining activ- 
ity of key enzymes responsible for the antioxidant cellular machinery. Aharoni et al. (2002) conducted a comprehensive investigation of gene expression during the maturation and nonclimacteric ripening of strawberry. As they desired to compare the gene expression of a ripening fruit with that of one exposed to oxidative stress, fruit were treated with the free-radical generator 2,2'-azobis (2-amidino-propane) dihydrochloride (AAPH). Of the 46 genes induced by oxidative stress, 20 were also found to be ripening related.

Rogiers et al. (1998) clearly showed that ripening of climacteric Saskatoon fruit is associated with a coincident rise in AOS that affects polar lipids. Lipid peroxidation during fruit ripening was evidenced by the accumulation of ethane and 2-thiobarbituric acid-reactive substances. Activities of SOD and CAT declined 4-fold and 18-fold, respectively, indicating the potential for the accumulation of cytotoxic levels of $\mathrm{H}_{2} \mathrm{O}_{2}$. Lipoxygenase activity increased 2.5 -fold during ripening, while reduced and oxidized forms of glutathione increased during the later stages of ripening. In ripening pepper fruits (Jimenez et al., 2003) higher ascorbate peroxidase and Mn-SOD activities in the mitochondria play a role in avoiding the accumulation of AOS. The presence of elevated levels of the antioxidant enzyme system implies that oxidative stress is a key factor during fruit and vegetable ripening.

\section{Ethylene}

Processes of ripening and senescence in fruits and vegetables are associated with oxidative mechanisms (Masai, 2003). Ethylene is commonly considered to be the ripening hormone and exposure of sensitive plant tissues to this phytohormone results in acceleration of both ripening and/or senescence (e.g., Hodges and Forney, 2000). However, oxidative processes such as lipid peroxidation, which are induced in some fruits in response to ethylene contact (Meir et al., 1991), appear to be secondary effects and not as a direct result of ethylene exposure (Toivenen, 2003). Additionally, many commodities are insensitive to ethylene and processes of ripening and senescence are not accelerated upon exposure to the hormone (Palou et al., 2003; Wise and Naylor, 1988). Ethylene synthesis is enhanced in association with environmental and biological stresses such as wounding or pathogen attack (Beaulieu et al., 1997; Morgan and Drew, 1997; Ohtsubo et al., 1999). Ethylene synthesis may be stimulated by AOS and lipoxygenase activity during membrane lipid peroxidation, further accelerating ripening and senescence processes (Hodges, 2003a).

\section{CONCLUSIONS}

Oxidative stress results from an organism's inability to cope with high levels of AOS. It would be tremendously tempting, but ultimately superficial, to attribute susceptibility to postharvest oxidative stress to either inherent increased AOS production and/or decreased antioxidant scavenging capacity. Many exogenous factors such as preharvest production practices, field stresses, harvesting techniques, commodity maturity, storage conditions, processing protocols, and transport and marketing procedures can interact with endogenous factors such as genotype, genetic up- or down-regulation, hormones, and/or general senescent/ripening processes to influence AOS levels, scavenging capacity, and ultimately postharvest oxidative stress of fruits and vegetables. With so many variables, it is often difficult to document or predict effects of exogenous and/or endogenous factors on postharvest oxidative stress. For example, with regards to antioxidant scavenging, studies of comparisons within commodities have demonstrated that genotypes exhibiting faster rates of postharvest quality decline concomitant with increased oxidative stress also exhibit lower and/or more rapidly declining antioxidant capacities (e.g., Lacan and Baccou, 1998; Toivonen and Sweeney, 1998; Hodges et al., 2001). However, the response of antioxidative systems to increasing oxidative stress during postharvest storage of fruits and vegetables does not appear to be consistent between species or cultivars/varieties within a species, underlying the complexity of antioxidant responses to oxidative stress (Hodges, 2001; Shewfelt and del Rosario, 2000; Toivonen, 2003). Nonetheless, a survey of recent research does suggest that the $\mathrm{H}_{2} \mathrm{O}_{2}$ and ascorbate metabolism are intrinsically associated with oxidative stress in postharvest storage situations (e.g., Hodges and Forney, 2000; Larrigaudiere et al., 2001; Hodges and Forney, 2003). Further understanding of the sequence of events in oxidative injury may lead to an improved ability to predict the development of postharvest oxidative stress.

\section{Literature Cited}

Abeles, F.B. 1973. Ethylene in plant biology. Academic Press, New York.

Aharoni, A., L.C.P. Keizer, H.C. Van Den Broeck, R. Blanco-Portales, J. Muñoz-Blanco, G. Bois, P. Smit, R.C.H. De Vos, and A.P. O'Connell. 2002. Novel insight into vascular stress, and auxin-dependent and -independent gene expression programs in strawberry, a nonclimacteric fruit. Plant Physiol. 129:1019-1031.

Ames, B.N., M.K. Shigenaga, and T.M. Hagen. 1993. Oxidants, antioxidants, and the degenerative diseases of aging. Proc. Nat. Acad. Sci. USA 90:7915-7922.

Barden, C.L. and W.J. Bramlage. 1994a. Acclimation of antioxidants in apple peel as related to preharvest factors and superficial scald susceptibility of the fruit. J. Amer. Soc. Hort. Sci. 119:264-269.

Barden, C.L. and W.J. Bramlage. 1994b. Relationships of antioxidants in apple peel to changes in $\alpha$-farnesene and conjugated trienes during storage and to susceptibility to superficial scald development after storage. Postharv. Biol. Technol. 4:23-33.

Barka, E.A. 2001. Protective enzymes against oxygen species during ripening of tomato (Lycopersicon esculentum) fruits in response to low amounts of UV-C. Austral. J. Plant Physiol. 28:785-791.

Barth, M.M. and H. Zhuang. 1996. Packaging design affects antioxidant vitamin retention and quality of broccoli during cabinet display. Postharv. Biol. Technol. 9:141-150.

Bartosz, G. 1997. Oxidative stress in plants. Acta Physiol. Plant. 19(1): 46-64.

Beaulieu, J.C., G. Peiser, and M.E. Saltveit. 1997. Acetaldeyde is a causal agent responsible for ethanol-induced ripening inhibition in tomato fruit. Plant Physiol. 113. 431-439.

Biedinger, U., R.J. Youngman, and H. Schnabl. 1990. Differential effects of electrofusion and electropermeabilization parameters on the membrane integrity of plant protoplasts. Planta 180:598-602.

Buchanan-Wollaston, V. 1997. The molecular biology of leaf senescence. J. Expt. Bot. 48:181-199.

Casano, L.M., H.R. Lacano, and V.S. Trippi. 1994. Hydroxyl radicals and a thylakoid-bound endopeptidase are involved in light and oxygen-induced proteolysis in oat chloroplasts. Plant Cell Physiol. 108:145-152.

Conklin, P.L. and R.L. Last. 1995. Differential accumulation of antioxidant mRNAs in Arabidopsis thaliana exposed to ozone. Plant Physiol. 109:203-212.

Connor, A.M., J.J. Luby, J.F. Hancock, S. Berkheimer, and E.J. Hanson. 2002. Changes in fruit antioxidant activity among blueberry cultivars during coldtemperature storage. J. Agr. Food Chem. 50:893-898.

Delledonne, M., I. Murgia, D. Ederle, P.F. Sbicego, A. Biondani, A. Polverari, and C. Lamb. 2001. Signal interactions between nitric oxide and reactive oxygen intermediates in the plant hypersensitive disease resistance response. Proc. Natl. Acad. Sci. USA 98:13454-13459.

DeLong, J.M. and R.K. Prange. 2003. Superficial scald - a postharvest oxidative stress disorder, p. 91-112. In: D.M. Hodges (ed.). Postharvest oxidative stress in horticultural crops. Food Products Press, New York.

Droillard, M.J., A. Paulin, and J.C. Massot. 1987. Free radical production, catalase, and superoxide dismutase activities and membrane integrity during senescence of petals of cut carnations (Dianthus caryophyllus). Physiol. Plant. 71:197-202.

Du, Z. and W.J. Bramlage. 1994. Superoxide dismutase activities in senescing apple fruit (Malus domestica Borkh.) J. Food Sci. 59:581-584.

Duque, P. and J.D. Arrabaça. 1999. Respiratory metabolism during cold storage of apple fruit. II. Alternative oxidase is induced at the climacteric. Physiol. Plant. 107:24-31.

Elstner,E.F. and W. Osswald. 1994. Mechanisms of oxygen activation during plant stress, p. 131-154. In: R.M.N. Crawford, G.A.F. Hendry, and B.A. Goodman (eds.). Oxygen and environmental stress in plants. Proceedings of the Royal Society of Edinburgh. vol. 102. Royal Soc. Edinburgh, Edinburgh, U.K.

Ferguson, I.B., C.B. Watkins, and J.E. Harman. 1983. Inhibition by calcium of senescence of detached cucumber cotyledons: effect on ethylene and hydroperoxide production. Plant Physiol. 71:182-186.

Forney, C.F. and W.J. Lipton. 1990. Influence of controlled atmospheres and packaging on chilling sensitivity, p. 257-267. In: C.Y. Wang (ed.). Chilling injury of horticultural crops. CRC Press Inc., Boca Raton, Fla.

Garcia-Yanez, M., A. Garcia-Arteaga, J. Fernandez-Miranda, A. Paradoa, E. Sampere, E. Castillo, and G. Serrano. 1990. Stability of vitamin C content in grapefruit treated with doses of gamma irradiation. Revista de Agroquimica y Tech. de Alimentos 30:409-415.

Gardner, H.W. and J.W. Newton. 1987. Lipid hydroperoxides in the conversion of 1-aminocyclopropane-1-carboxylic acid to ethylene. Phytochem. 26:621-626. 
German J.B., E.N. Frankel, A.L. Waterhouse, R.J. Hansen, R.L.Walzem, and T.R.Watkins. 1997. Wine phenolics and targets of chronic disease. Wine nutritional and therapeutic benefits, p. 196-214. In: T.R. Watkins (ed.). Wine: nutritional and therapeutic benefits. Amer. Chem. Soc. Symp. Ser. 661.

Gil, M.I., F. Ferreres, and F.A. Tomás-Barberán. 1999. Effect of postharvest storage and processing on the antioxidant constituents (flavonoids and vitamin C) of fresh-cut spinach. J. Agr. Food Chem. 47:2213-2217.

Giovanelli, G., V. Lavelli, C. Peri, and S. Nobili. 1999. Variation in antioxidant components of tomato during vine and post-harvest ripening. J. Agr. Food Chem. 79:1583-1588.

Gong, Y., P.M.A. Toivonen, O.L. Lau, and P.W. Wiersma. 2001. Antioxidant system level in 'Braebrun' apple is related to its browning disorder. Bot. Bul. Acad. Sin. 42:259-264.

Gossett, D.R., E.P. Millhollon, and M.C. Lucas. 1994. Antioxidant response to $\mathrm{NaCl}$ stress in salt-tolerant and salt-sensitive cultivars of cotton. Crop Sci. 34:706-714.

Gunes, G., R.H. Liu, and C.B. Watkins. 2002. Controlled-atmosphere effects on postharvest quality and antioxidant activity of cranberry fruits. J. Agr. Food Chem. 50:5932-5938.

Halliwell, B. 1996. Mechanisms of ageing and development. Annu. Rev. Nutr. 16:33-50.

Hideg, E., J. Mano, C. Ohno, and K. Asada. 1997. Increased levels of monodehydroascorbate radical in UV-B irradiated broad bean leaves. Plant Cell Physiol. 38:684-690.

Hodges, D.M. 2001. Chilling effects on active oxygen species and their scavenging systems in plants, p. 53-76. In: A.S. Basra (ed.). Crop responses and adaptations to temperature stress. Food Products Press, New York.

Hodges, D.M. 2003a. Overview: Oxidative stress and postharvest produce, p. 1-12. In: D.M. Hodges (ed.). Postharvest oxidative stress in horticultural crops. Food Products Press, New York.

Hodges, D.M. 2003b. Postharvest oxidative stress in horticultural crops. Food Products Press, New York.

Hodges, D.M., C.J. Andrews, D.A. Johnson, and R.I. Hamilton. 1997. Antioxidant enzyme responses to chilling stress in differentially sensitive inbred maize lines. J. Expt. Bot. 48:1105-1113.

Hodges, D.M. and C.F. Forney. 2000. The effects of ethylene, depressed oxygen and elevated carbon dioxide on antioxidant profiles of senescing spinach leaves. J. Expt. Bot. 51:645-655.

Hodges, D.M. and C.F. Forney. 2003. Postharvest ascorbate metabolism in two cultivars of spinach differing in their senescence rates. J. Amer. Soc. Hort. Sci. 128:930-935.

Hodges, D.M. and W. Kalt. 2003. Health functionality of small fruit. Acta Hort. 626:17-23.

Hodges, D.M., W.V. Wismer, and C.F. Forney. 2000. Processing line effects on storage attributes of fresh spinach leaves. HortScience. 35:1308-1311.

Hodges, D.M., W.V. Wismer, and C.F. Forney. 2001. Antioxidant responses in postharvest leaves of two cultivars of spinach (Spinacia oleracea L.) differing in their senescence rates. J. Amer. Soc. Hort. Sci. 126:611-617.

Jiménez, A., F. Romojaro, J.M. Gomez, M.R. Llanos, and F. Sevilla. 2003. Antioxidant systems and their relationship with the response of pepper fruits to storage at 20 degrees C. J. Agr. Food Chem. 51:6293-6299.

Jones, J.L. and B.B. Bulford. 1990. A feasibility study of the use of DNA fragmentation as a method for detecting irradiation of food. Campden Food and Drink Res. Assn. Tech. Memo. 584

Kader, A.A. 1986. Potential applications of ionizing radiation in postharvest handling of fresh fruits and vegetables. Food Technol. 40: 117-121.

Kalt, W., C. Lawand, D.A.J. Ryan, J.E. McDonald, H. Donner, and C.F. Forney. 2003. Oxygen radical absorbing capacity, anthocyanin and phenolic content of highbush blueberries (Vaccinium corymbosum L.) during ripening and storage. J. Amer. Soc. Hort. Sci. 128:917-923.

Kunert K.J. and M. Ederer. 1985. Leaf aging and lipid peroxidation: The role of the antioxidants vitamin C and E. Physiol. Plant. 65:85-88.

Lacan D. and J.-C. Baccou. 1998. High levels of antioxidant enzymes correlate with delayed senescence in nonnetted muskmelon fruits. Planta 204:377-382.

Landry, L.G. and E.J. Pell. 1993. Modification of rubisco and altered proteolytic activity in $\mathrm{O}_{3}$-stressed hybrid poplar (Populus maximowizii ×trichocarpa). Plant Physiol. 101:1355-1362.

Larrigaudiere, C., I. Lentheric, E. Pinto, and M. Vendrell. 2001. Short-term effects of air and controlled atmospheres storage on antioxidant metabolism in conference pears. J. Plant Physiol. 158:1015-1022.

Lee, H.S., E.J. Kwon, S.Y. Kwon, Y.J. Jeong, E.M. Lee, M.H. Jo, H.S. Kim, I.S Woo, A. Shinmyo, K. Yoshida, and S.S. Kwak. 2003. Transgenic cucumber fruits that produce elevated levels of an anti-aging superoxide dismutase. Mol. Breed. 11:213-220.

Lentheric, I., E. Pintó, J. Graell, and C. Larrigaudiere. 2003. Effects of $\mathrm{CO}_{2}$ pretreatment on oxidative metabolism and core-browning incidence in controlled atmosphere stored pears. J. Hort. Sci. Biotechnol. 78:177-181.
Lester, G.E. 2003. Oxidative stress affecting fruit senescence, p. 113-129. In: D.M. Hodges (ed.). Postharvest oxidative stress in horticultural crops. Food Products Press, New York.

Lester, G.E. and B.D. Bruton. 1986. Relationship of netted muskmelon fruit water loss to postharvest storage life. J. Amer. Soc. Hort. Sci. 111:727-731.

Lester, G.E. and M.A. Grusak. 1999. Postharvest application of calcium and magnesium to honey dew and netted muskmelons: Effects on tissue ion concentrations, quality, and senescence. J. Amer. Soc. Hort. Sci. 124:545-552

Lester, G.E. and D.A. Wolfenbarger. 1990. Comparisons of cobalt-60 gamma irradiation doses rates on grapefruit flavedo tissue and on mexican fruit fly mortality. J. Food Protect. 53:329-331.

Li, L., J. Van Staden, and A.K. Jäger. 1998. Effects of plant growth regulators on the antioxidant system in seedlings of two maize cultivars subjected to water stress. Plant Growth Reg. 25:81-87.

Lurie, S. 1998. Postharvest heat treatments. Postharv. Biol. Techol. 14:257269.

Masia, A. 1998. Superoxide dismutase and catalase activities in apple fruit during ripening and post-harvest and with special reference to ethylene. Physiol. Plant. 104: 668-672.

Masia, A. 2003. Physiological effects of oxidative stress in relation to ethylene in postharvest produce, p. 165-197. In: D.M. Hodges (ed.). Postharvest oxidative stress in horticultural crops. Food Products Press, New York.

Maxie, E.C. and A. Abdel-Kader. 1966. Food irradiation-Physiology of fruits as related to feasibility of the technology. Adv. Food Res. 15: 105-145.

Meir, S., S. Philosoph-Hadas, G. Zauberman, Y. Fuchs, M. Akerman, and N. Aharoni. 1991. Increased formation of fluorescent lipid-peroxidation products in avocado peels proceeds other signs of ripening. J. Amer. Soc. Hort. Sci. 116:823-826.

Meydani, M. 1999. Dietary antioxidants modulation of aging and immuneendothelial cell interaction. Mech. Ageing Dev. 111:123-132.

Mitchell, G.E., R.L. McLauchlan, T.R. Beattie, C. Banos, and A.A. Gillen. 1990. Effect of gamma irradiation on the carotene content of mangos and red capsicums. J. Food Sci. 55:1185-1186.

Millter, R. 2002. Oxidative stress, antioxidants and stress tolerance. Trends Plant Sci. 7(9):405-410.

Morgan, P.W. and M.C. Drew. 1997. Ethylene and plant responses to stress. Physiol. Plant.100:620-630.

Noodén, L.D. 1988. The phenomena of senescence and aging, p. 1-50. In: L.D Noodén and A.C. Leopold (eds.). Senescence and aging in plants. Academic Press, San Diego, Calif.

Noodén, L.D. and J.J. Guiamét. 1989. Regulation of assimilation and senescence by the fruit in monocarpic plants. Physiol. Plant. 77:267-274.

Ohtsubo, N., I. Mitsuhara, M. Koga, S. Seo, and Y. Ohashi. 1999. Ethylene promotes the necrotic lesion formation and basic PR genes expression in TMV-infected tobacco. Plant Cell Physiol. 40: 808-817.

Palou, L. C.H. Crisosto, D. Garner, and L.M. Basinal. 2003. Effect of continuous exposure to exogenous ethylene during cold storage on postharvest decay development and quality attributes of stone fruits and table grapes. Postharv. Biol. Technol. 27:243-254.

Parkin, K.L. and S.-J. Kuo. 1989. Chilling-induced lipid degradation in cucumber (Cucumis sativa L. cv. Hybrid C) fruit. Plant Physiol. 90:1049-1056.

Paulin, A., M.J. Droillard, and J.M. Bureau.1986. Effect of a free radical scavenger 3,4,5-trichlorophenol, on ethylene production and on changes in lipids and membrane integrity during senescence of petals of cut carnations (Dianthus caryophyllus). Physiol. Plant. 67:465-471.

Pell, E.J., C.D. Schlagnhaufer, and R.N. Arteca. 1997. Ozone-induced oxidative stress: Mechanisms of action and reaction. Physiol. Plant. 100:264-273.

Pesis, E., D. Aharoni, Z. Aharon, R. Ben-Arie, N. Aharoni, and Y. Fuchs. 2000 Modified atmosphere and modified humidity packaging alleviates chilling injury symptoms in mango fruit. Postharv. Biol. Technol. 19:93-101.

Philosoph-Hadas, S., S. Meir, B. Akiri, and J. Kanner. 1994. Oxidative defense systems in leaves of three edible herb species in relation to their senescence rate. J. Agr. Food Chem. 42:2376-2381.

Pirker, K.F., B.A. Goodman, E.C. Pascual, S. Kiefer, G. Soja, and T.G Reichenauer. 2002. Free radicals in the fruit of three strawberry cultivars exposed to drought stress in the field. Plant Physiol. Biochem. 40:709-717.

Poskuta, J., M. Mikulska, M. Faltynowicz, B. Bielak, and B. Wroblewska. 1974. Chloroplast development. Zeitschrift Pflanzenphysiol. 73:387-393.

Price, A.H., A. Taylor, S.J. Ripley, A. Griffiths, A.J. Trewavas, and M.R. Knight. 1994. Oxidative signals in tobacco increase with cytosolic calcium. Plant Cell 6:1301-1310.

Purvis, A.C. and R.L. Shewfelt. 1993. Does the alternative pathway ameliorate chilling injury in sensitive plant tissues? Physiol. Plant. 88:712-718.

Purvis, A.C., R.L. Shewfelt, and J.W. Gegogeine. 1995. Superoxide production by mitochondria isolated from green bell pepper fruit. Physiol. Plant. 94:743-749.

Rogiers, S.Y., G.N.M. Kumar, and N.R. Knowles. 1998. Maturation and ripen- 
ing of fruit of Amelanchier alnifolia Nutt. are accompanied by increasing oxidative stress. Ann. Bot. 81:203-211.

Sala, J.M. 1998. Involvement of oxidative stress in chilling injury in cold-stored mandarin fruits. Postharv. Biol. Technol. 13:255-261.

Saran, M., C. Michel, and W. Bors. 1988. Reactivities of free radicals, p. 76-92. In: S. Schulte-Hostede, N.M. Darrall, L.W. Blank, and A.R. Wellburn (eds.) Air pollution and plant metabolism. Elsevier, London, U.K.

Schmitz-Eiberger, M. and G. Noga. 2001. UV-B radiation: Influence on antioxidative components in Phaseolus vulgaris leaves. J. Appl. Bot. 75:210-215

Shewfelt, R.L. and B.A. del Rosario. 2000. The role of lipid peroxidation in storage disorders of fresh fruits and vegetables. HortScience 35:575-579.

Strydom, G.J., J. van Staden, and M.T. Smith. 1991. The effect of gamma radiation on the ultrastructure of the peel of banana fruits. Environ. Expt. Bot. 31: 43-49.

Thompson, J.E., J.H. Brown, G. Paliyath, J.F. Todd, and K. Yao. 1991. Membrane phospholipid catabolism primes the production of activated oxygen in senescing tissues, p. 57-66. In:E.J. Pell and K.L. Steffen (eds.). Active oxygen/oxidative stress and plant metabolism. Amer. Soc. Plant Physiol., Rockville, Md.

Toivonen, P.M.A. 2003. Effects of storage conditions and postharvest procedures on oxidative stress in fruits and vegetables, p. 69-90. In: D.M. Hodges (ed.). Postharvest oxidative stress in horticultural crops. Food Products Press, New York.

Toivonen, P.M.A. and M. Sweeney. 1998. Differences in chlorophyhll loss at $13{ }^{\circ} \mathrm{C}$ for two broccoli (Brassica oleracea $\mathrm{L}$.) cultivars associated with antioxidant enzyme activities. J. Agr. Food Chem. 46: 20-24.

Toyo'oka, T., S. Uchiyama, and Y. Saito. 1989. Effect fo gamma-irradiation on thiol compounds in grapefruit. J. Agr. Food Chem. 37:769-775.

Voisine, R., L.P. Vezina, and C. Willemont. 1991. Induction of senescence-like deterioration of microsomal membranes from cauliflower by free radicals generated during gamma irradiation. Plant Physiol. 97:545-550.

Wang, S.Y. and H.-S. Lin. 2000. Antioxidant activity in fruits and leaves of blackberry, raspberry, and strawberry varies with cultivar and developmental stage. J. Agr. Food Chem. 48:140-146.

Watkins, C.B. and M.V. Rao. 2003. Genetic variation and prospects for genetic engineering of horticultural crops for resistance to oxidative stress induced by postharvest conditions, p. 199-224. In: D.M. Hodges (ed.). Postharvest oxidative stress in horticultural crops. Food Products Press, New York.

Wise, R.R. and A.W. Naylor. 1988. Stress ethylene does not originate directly from lipid peroxidation during chilling-enhanced photooxidation. J. Plant Physiol. 133:62-66.

Wismer, W.V. 2003. Low temperature as a causative agent of oxidative stress in postharvest crops, p. 55-68. In: D.M. Hodges (ed.). Postharvest oxidative stress in horticultural crops. Food Products Press, New York.

Yan, J.Q., J. Wang, D. Tissue, A.S. Holiday, R. Allen, and H. Zhang. 2003. Photosynthesis and seed production under water-deficit condition in transgenic tobacco plants that over-express an Arabidopsis ascorbate peroxidase gene. Crop Sci. 43:1477-1483.

Yang, Y.-J. 1997. Effect of controlled atmospheres on storage life in 'Niitaka' pear fruit. J. Kor. Soc. Hort. Sci. 38:734-738.

Zabrouskov, V., G.N.M. Kumar, J.P. Spychalla, and N.R. Knowles. 2002. Oxidative metabolism and the physiological age of seed potatoes are affected by increased $\alpha$-linolenate content. Physiol. Plant. 116:172-185.

Zhuang, H., M.M. Barth, and D.F. Hildebrand. 1994. Packaging influenced total chlorophyll, soluble protein, fatty acid composition and lipoxygenase activity in broccoli florets. J. Food Sci. 59:1171-1174.

Zhuang, H., D.F. Hildebrand, and M.M. Barth. 1997. Temperature influenced lipid peroxidation and deterioration in broccoli buds during postharvest storage. Postharv. Biol. Technol. 10:49-58. 